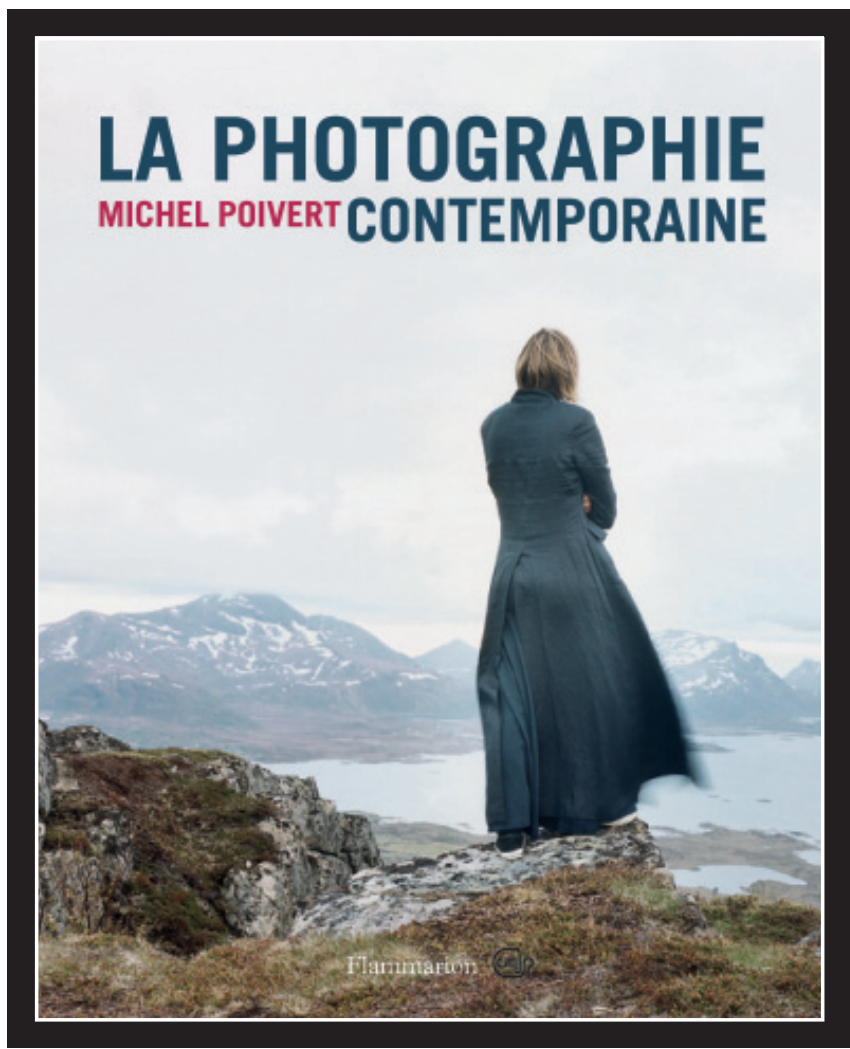

La Photographie contemporaine, de Michel Poivert, $2^{a}$ edição (revista e ampliada), Editora Flammarion (Paris), 2010, 239 p. ISBN 978-2-0812-2415-5. 


\title{
A fotografia contemporânea: reestabelecendo o valor da image
}

Contemporany photography: reestablishing the value of de image

\author{
Andrea Eichenberger*
}

Como caracterizar a fotografia que vem sendo produzida a partir do final do século XX e compreender o que não é nem um movimento artístico, nem uma simples categoria da arte contemporânea? É esta reflexão que Michel Poivert ${ }^{1}$ se propõe fazer no livro La photographie contemporaine, inicialmente publicado em 2002, e posteriormente ampliado e reeditado em 2010. O ensaio inscreve-se no conjunto de trabalhos cuja tradição crítica ganhou relevo com as transformações do meio e com os aprofundamentos do próprio conceito de fotografia, em constante e complexa articulação com os conceitos de arte e documento.

Neste sentido, trata-se de uma obra de fôlego que se pode situar na esteira da história e da teoria da fotografia. O autor faz parte das novas gerações de pensadores franceses que discutem o tema, percebendo-o em seu cruzamento com as formas alternativas de informação na era das novas mídias, com a questão documental em uma época em que a arte deixa de ser o único horizonte de criação e com o questionamento do próprio estatuto de obra de arte e de representação, assuntos que vem sendo continuamente reavaliados, tanto por pesquisadores quanto por artistas.

É trabalhando com a ideia de "originalidade da fotografia", ou seja, considerando sua essência (de ser imagem), sendo assumida e aceita "como

\footnotetext{
* Fotógrafa. Doutora e mestre em antropologia visual. Graduada em artes visuais. Atualmente, desenvolve estágio pós-doutoral em Fotografia na Université Paris I - Panthéon Sorbonne, e está vinculada aos grupos de pesquisa HiCSA (Histoire Culturelle et Sociale de l'Art)/Université Paris I, Anthropologie et Photographie/Université Paris 7 e NAVI (Núcleo de Antropologia Audiovisual e Estudos da Imagem)/UFSC.

${ }^{1}$ Crítico, curador e professor de História da Arte Contemporânea/História da Fotografia na Université Paris 1-Panthéon-Sorbonne.
} 
possibilidade de experimentação" que Michel Poivert atravessa a fotografia em toda a sua diversidade, abordando tanto a fotografia experimental quanto a estética documental e a imagem performatizada. Afirmando, de saída, que "o horizonte da fotografia contemporânea não se limita à sua finalidade artística", o autor propõe uma reflexão apurada que, ao mesmo tempo em que nega à fotografia uma verdadeira autonomia, descarta sua fusão com o campo da arte de uma forma geral. Para Poivert, "considerar a contemporaneidade da fotografia" implica reconhecer "à arte o papel de referência maior, mas observando, para além dessa referência, a extensão do campo de ação estético e ético das práticas e das produções fotográficas".

Neste sentido, Poivert se pergunta: "Do que a fotografia contemporânea é contemporânea?"E sugere como resposta: "A fotografia, antes de tudo, é contemporânea da arte." Para o autor, uma história comum à arte e à fotografia inicia nos anos 1980, fundamentada pela conscientização do fotógrafo no que concerne a construção da imagem, bem como por sua preocupação em redefinir-lhe valores na era da comunicação. E éa partir dessa perspectiva que as relações entre fotografia e arte estabelecidas no ensaio são mediadas: por recusa e por adesão, por desafios em todo caso.

O texto de Michel Poivert é atravessado, do início ao fim, pela questão do "moderno", que vem a ser o elemento através do qual o autor propõe uma estrutura histórica para a fotografia contemporânea. A "condição moderna" é destacada em seu ensaio através de uma análise que perpassa a "modernidade", o "modernismo", o "antimodernismo", o "pós-moderno", enfim, as diversas variações do conceito, do início do século passado à época atual.

A partir daí, ao longo de seis capítulos, o autor revisa a história e a condição da fotografia para pensar sua contemporaneidade. Diversas questões são contempladas: a "ética do moderno", a "condição experimental", a "crise dos usos", a "autoridade da fotografia", a "utopia documental" e o "destino da imagem performatizada". Dessa incursão téorico-histórica, onde as categorias não se excluem e onde algumas 
problemáticas se cruzam, se destaca o questionamento em torno do "valor da imagem", ou de sua essência, que suscita uma importante reavaliação do uso artístico/documental da fotografia, abrindo novas perspectivas para pensar o campo. Neste sentido, a originalidade do seu texto é bem-vinda hoje.

Por outro lado, talvez seja oportuno sublinhar que o livro de Michel Poivert, repleto de reproduções de imagens dos fotógrafos citados no decorrer do ensaio, não deixa de se concentrar no eixo Europa-EUA, fora algumas poucas exceções representadas por fotógrafos de outras origens. Assim, podemos então perguntar: isso não consistiria em reforçar uma história e teoria da fotografia concebidas a partir de uma velha perspectiva? É impossível não considerar a multiplicidade de influências provenientes do exterior e a nossa extraordinária permeabilidade face ao que vem sendo produzido fora do país. No entanto, recebemos essas influências adaptando-as às nossas idiossincrasias. No que implicaria, então, tomar o trabalho de Poivert para pensar a fotografia contemporânea brasileira? Seria possível construir algo nosso estabelecendo paralelos com as reflexões do autor? Talvez estas e outras questões que a excelente obra pode sugerir sejam apenas um sinal de que ela não fecha, antes, abre muitas e interessantes possibilidades de estudo e pesquisa. 